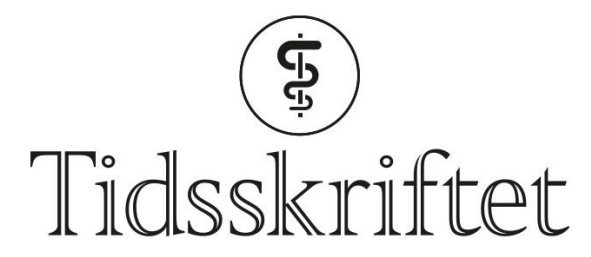

DEN NORSKE LEGEFORENING

\title{
Forside nr. 2/2021
}

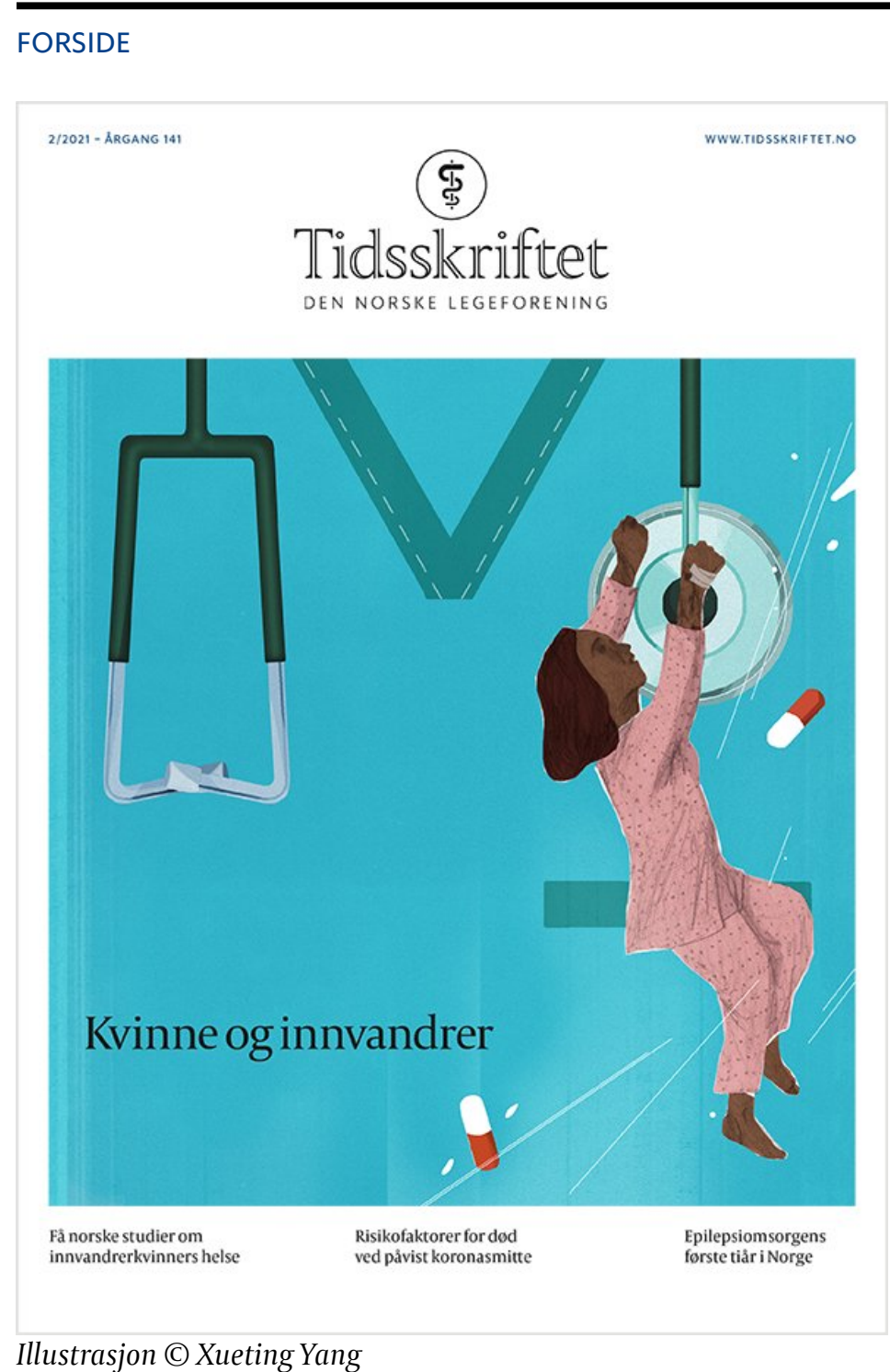

Tema for forsiden er helse hos innvandrerkvinner. - Jeg føler nærhet til dette temaet, sier Xueting Yang, som har illustrert forsiden. - Jeg har selv innvandret fra Kina for ti år siden og kjenner meg igjen i hvordan man føler seg bortkommen, fremmed og sårbar i møte med et ukjent helsevesen. Så jeg tegnet en kvinne som strever med å fange legen, fange mulighetene som legen kan gi henne. Flere av Yangs arbeider finner du her: www.xueting.no 